\title{
Renal Pelvis and Ureter Carcinoma
}

National Cancer Institute

\section{Source}

National Cancer Institute. Renal Pelvis and Ureter Carcinoma. NCI Thesaurus. Code C7515.

Carcinoma that affects the renal pelvis and ureter. 